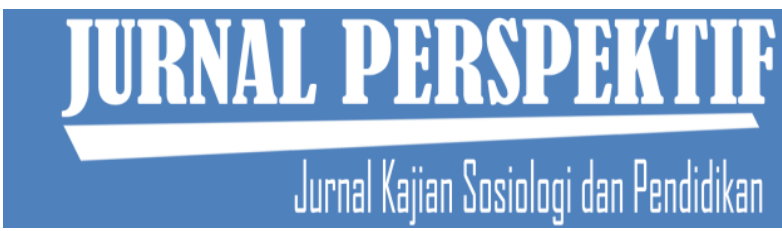

Jurnal Perspektif: Jurnal Kajian Sosiologi dan Pendidikan Vol. 2 No. 2 Tahun 2019

http://perspektif.ppj.unp.ac.id

Email: perspektif@ppj.unp.ac.id

ISSN: 2622-1748 (Online), 2684-902X (Print)

DOI: http://dx.doi.org/10.24036/perspektif.v2i2.66

\title{
Implementasi Peraturan Daerah Nomor 3 Tahun 2015 Tentang Pemenuhan dan Perlindungan Hak-Hak Penyandang Disabilitas di Kota Padang
}

\author{
Dio Yoan Sabrina ${ }^{1}$, Erianjoni Erianjoni ${ }^{2}$ \\ 1,2Universitas Negeri Padang \\ email: diosabrin4@gmail.com, erian_joni@yahoo.com
}

\begin{abstract}
Abstrak
Penelitian ini bertujuan untuk mengetahui implementasi Peraturan Daerah Nomor 3 Tahun 2015 tentang pemenuhan dan perlindungan hak-hak penyandang disabilitas di Kota Padang. Penelitian ini dianalisis dengan teori Struktural Fungsional yang dikemukakan oleh Talcott Parsons dengan menggunakan fungsi AGIL (Adaptation, Goal Attainment, Integration, Latten Pattern Maintenance). Penelitian ini menggunakan pendekatan kualitatif tipe deskriptif, teknik pemilihan informan purposive sampling dengan jumlah informan sebanyak 11 orang. Pengumpulan data dilakukan dengan cara observasi non partisipatif, wawancara mendalam, studi dokumentasi, dan studi kepustakaan yang dianalisis dengan menggunakan teknik analisis data dari Miles dan Huberman. Hasil penelitian menunjukkan bahwa Peraturan Daerah Kota Padang Nomor 3 Tahun 2015 telah diimplementasikan namun belum terimplementasi sesuai dengan tujuan. Dalam hal ini, Pemerintah Kota Padang telah menyediakan aksesibilitas fisik sebagai salah satu akses dalam mewujudkan pemenuhan dan perlindungan hak-hak penyandang disabilitas di Kota Padang. Pemerintah Kota Padang juga telah berusaha mensosialisasikan aksesibilitas untuk penyandang disabilitas melalui Dinas Sosial Kota Padang. Namun implementasinya belum sesuai dengan tujuan yang diharapkan.
\end{abstract}

Kata kunci: Aksesibilitas, Penyandang Disabilitas

\begin{abstract}
This study aims to determinate the implementation of Padang City Legal Regulation Number 3 of 2015 about fulfillment and protection the rights of person with disabilities in Padang City. This research was analyzed by the structural functional theory proposed by Talcott Parsons with the function of AGIL (Adaptation, Goal Attainment, Integration, Latten Pattern Maintenance). This research uses a qualitative approach with descriptive type, for the informant selection technique uses purposive sampling with 11 informants. Data collection done by observation non partisipative, in depth interview, documentation study, and literature studi analyzed by using data analysis technique from Miles and Huberman. The result of this research are showing that implementation of Padang City Legal Regulation Number 3 of 2015 has done but has not been suits with the purpose yet. Padang government have tried to provide physical accessibility as one of accses to personalize fulfillment and protection the rights of person with disabilities in Padang City. Padang government also has tried to socialize accessibility for person with disabilities through Department of Social in Padang City. But, the implementation has not suited with the purpose yet.
\end{abstract}

Keyword: Accessibility, Person with Disabilities 
Dio Yoan Sabrina, Erianjoni Erianjoni

Implementasi Peraturan Daerah Nomor 3 Tahun 2015

\section{Pendahuluan}

Penyandang disabilitas adalah orang yang mengalami keterbatasan fisik, intelektual, mental, dan/atau sensorik dalam jangka waktu lama yang dalam berinteraksi dengan lingkungan dapat mengalami hambatan dan kesulitan untuk berpartisipasi secara penuh dan efektif dengan warga negara lainnya berdasarkan kesamaan hak ${ }^{1}$. Pemerintah Indonesia memiliki kewajiban memenuhi hak dan memberikan perlindungan terhadap penyandang disabilitas. Ini sesuai dengan Peraturan Perundang-undangan Nomor 8 Tahun 2016 yang secara khusus memberikan landasan hukum yang kuat dalam memperjuangkan persamaan hak bagi penyandang disabilitas. Undang-undang Nomor 8 tahun 2016 Pasal 27 menjelaskan bahwasanya pemerintah dan pemerintah daerah wajib melakukan perencanaan, penyelenggaraan, dan evaluasi tentang pelaksanaan penghormatan, pelindungan, dan pemenuhan hak penyandang disabilitas ${ }^{2}$.

Hal tersebut dibuktikan dengan adanya Peraturan Daerah Kota Padang Nomor 3 Tahun 2015 tentang pemenuhan dan perlindungan hak-hak penyandang disabilitas Kota Padang. Dalam mengadakan suatu pembangunan, Pemerintah Kota Padang selalu memperhatikan segala aspek yang berkaitan dengan pemenuhan dan perlindungan hak-hak penyandang disabilitas. Agar nantinya segala pembangunan yang telah dibuat dapat diakses oleh seluruh masyarakat termasuk penyandang disabilitas yang ada di Kota Padang.

Pada tahun 2017, penduduk Kota Padang mencapai 927.168 jiwa $^{3}$. Badan Pusat Statistik telah melakukan sebuah survey tentang jumlah penyandang disabilitas di Kota Padang. Dari 927.168 jiwa, BPS Kota Padang mengambil 1601 orang untuk dijadikan sampel. Dari survey tersebut, BPS Kota Padang mendapatkan data bahwa jumlah penyandang disabilitas di Kota Padang sebanyak 182 orang dengan pembagian kesulitan/ gangguan melihat sebanyak 116 orang, kesulitan/gangguan mendengar sebanyak 46 orang, kesulitan/gangguan berjalan sebanyak 76 orang, kesulitan/gangguan memegang sebanyak 38 orang, kesulitan/gangguan berbicara sebanyak 23 orang, dan kesulitan/gangguan lainnya sebanyak 37 orang. Dinas Sosial Kota Padang juga telah mendata jumlah anak dengan kedisabilitasan dan penyandang disabilitas masing-masing adalah 1630 orang dan 1411 orang. Data ini didapat dari Rekapitulasi Pendataan Penyandang Masalah Kesejahteraan Sosial Tahun 2018.

Sesuai dengan Peraturan Daerah Kota Padang Nomor 3 Tahun 2015 pasal 96 yaitu penyediaan aksesibilitas yang berbentuk fisik sebagaimana dimaksud pada Pasal 95 ayat (2) huruf a, terdiri dari ${ }^{4}:$ a). Aksesibilitas pada bangunan gedung umum; b). Aksesibilitas pada jalan umum maupun khusus; c). Aksesibilitas pada pertamanan dan pemakaman umum; d). Aksesibilitas pada pelabuhan dan bandar udara; e). Aksesibilitas pada transportasi umum; f). Aksesibilitas pada pusat perbelanjaan dan perkantoran; g). Aksesibilitas pada layanan perbankan dan jasa keungan lainnya; h). Aksesibilitas pada rumah sakit, dan layanan medis lainnya; i). Aksesibilitas layanan pendidikan san kebudayaan; dan j). Penyelenggaraan pelayanan publik lainnya. Namun pada kenyataannya, pembangunan yang telah dibangun oleh Pemerintah Kota Padang belum optimal dalam memberikan aksesibilitas untuk penyandang disabilitas. Hal tersebut secara umum dapat dilihat karena kurangnya sosialisasi

\footnotetext{
${ }^{1}$ Undang-undang Republik Indonesia, Undang-undang RI Nomor 8 Tahun 2016 tentang Penyandang Disabilitas. BAB I. Pasal 1, Ayat 1 hlm. 2

${ }^{2}$ Fernandes, R. (2018). ADAPTASI SEKOLAH TERHADAP KEBIJAKAN PENDIDIKAN INKLUSIF. SOCIUS, 4(2 December), 119-125.

${ }^{3}$ Peraturan Daerah Kota Padang, Peraturan Daerah Kota Padang Nomor 3 Tahun 2015 tentang Pemenuhan dan Perlindungan Hak-hak Penyandang Disabilitas, BAB 1, Pasal 1, Ayat 18, Hlm. 5

${ }^{4}$ Ibid, Hlm. 26
}

Jurnal Perspektif Vol. 2, No. 2, Th. 2019 
Dio Yoan Sabrina, Erianjoni Erianjoni

Implementasi Peraturan Daerah Nomor 3 Tahun 2015

Tentang Pemenuhan dan Pelindungan Hak-hak Penyandang Disabilitas di Kota Padang

yang diberikan oleh Pemerintah Kota Padang kepada seluruh masyarakat Kota Padang. Pemilik atau pengelola bangunan juga kurang memahami dan mengetahui apa tujuan dibuatnya pembangunan fisik yang aksibel. Lalu masih banyak masyarakat termasuk penyandang disabilitas yang minim pengetahuan mengenai aksesibilitas pada bangunan dan fasilitas umum.

Karena, pembangunan-pembangunan yang telah dibuat oleh pemerintah Kota Padang tidak digunakan secara optimal oleh masyarakat terkhususnya penyandang disabilitas. Kurangnya sosialisasi, pengetahuan, dan kesadaran dari Pemerintah Kota Padang dan seluruh lapisan masyarakat adalah salah satu faktornya. Atas dasar Peraturan Daerah Kota Padang Nomor 3 Tahun 2015 tentang pemenuhan dan perlindungan hak-hak penyandang disabilitas perlu ditinjau implementasinya dalam memenuhi dan melindungi hak-hak penyandang disabilitas.

\section{Metode Penelitian}

Penelitian ini menggunakan pendekatan kualitatif dengan tipe deskriptif. Menurut Creswell penelitian kualitatif adalah suatu proses penelitian ilmiah yang lebih dimaksudkan untuk memahami masalah-masalah manusia dalam konteks sosial dengan menciptakan gambaran menyeluruh dan kompleks yang disajikan, melaporkan pandangan terperinci dari para sumber informasi, serta dilakukan dalam setting yang alamiah tanpa adanya intervensi apa pun dari peneliti ${ }^{5}$. Sedangkan menurut Sukmadinata penelitian kualitatif yaitu suatu penelitian yang ditujukan untuk mendeskripsikan dan menganalisis fenomena, peristiwa, aktivitas sosial, sikap, kepercayaan, persepsi, pemikiran orang secara individu maupun kelompok $^{6}$. Dalam penelitian ini menggunakan penelitian kualitatif tipe deskriptif, di mana penelitian deskriptif adalah metode kualitatif untuk mendapatkan data yang mendalam, suatu data yang mengandung makna ${ }^{7}$. Tipe deskriptif dipilih karena penelitian yang dilakukan adalah berkaitan dengan peristiwa-peristiwa yang sedang berlangsung dan berkenaan dengan kondisi masa sekarang. Dalam penelitian ini, peneliti mengambil tipe penelitian deskriptif karena tipe penelitian ini akan memberikan "deskripsi yang padat" yang penting bagi penelitian mengenai studi penerapan Peraturan Daerah Kota Padang Nomor 3 Tahun 2015 tentang pemenuhan dan perlindungan hak-hak penyandang disabilitas.

Subjek penelitian ini adalah Kepala Seksi Rehabilitasi Sosial Penyandang Disabilitas, Dinas Sosial Kota Padang, Kepala Seksi Diseminasi Layanan Statistik, Badan Pusat Statistik Sumatera Barat, Sekertaris Himpunan Wanita Disabilitas Indonesia, Sumatera Barat (HWDI Sumbar), Kepala Bidang Bina Program Dinas Pekerjaan Umum Kota Padang, penyandang disabilitas dan masyarakat pengguna aksesibilitas di Kota Padang. Teknik pengambilan data dalam penelitian ini adalah dengan menggunakan teknik purposive sampling atau sampe bertujuan dengan jumlah informan sebanyak 11 orang. Adapun teknik pengumpulan data yang digunakan dalam penelitian ini yaitu observasi non partisipatif, wawancara mendalam, studi dokumentasi, dan studi kepustakaan. Obeservasi non partisipatif adalah suatu bentuk observasi di mana peneliti tidak terlibat langsung dalam kegiatan kelompok, atau dapat juga

\footnotetext{
${ }^{5}$ Haris Herdiansyah, Metode Penelitian Kualitatif Untuk Ilmu-ilmu Sosial, ( Jakarta: Salemba Humanika, 2014), hlm. 8

${ }^{6}$ Nana Syaodih Sukmadinata, Metode Penelitian Pendidikan, (Bandung: PT. Remaja Rosdakarya, 2007), hlm. 60

${ }^{7}$ Sugiyono, Memahami Penelitian Kualitatif, (Bandung: Alfabeta, 2013), hlm. 3
}

Jurnal Perspektif Vol. 2, No. 2, Th. 2019 
Dio Yoan Sabrina, Erianjoni Erianjoni Implementasi Peraturan Daerah Nomor 3 Tahun 2015 Tentang Pemenuhan dan Pelindungan Hak-hak Penyandang Disabilitas di Kota Padang

dikatakan peneliti tidak ikut serta dalam kegiatan yang diamatinya ${ }^{8}$. Wawancara mendalam (in-depth interview) adalah suatu kejadian atau proses interaksi antara pewawancara (interviewer) dan sumber informasi atau orang yang diwawancarai (interviewee) melalui komunikasi langsung9. Peneliti langsung brtatap muka dengan informan dengan menggunakan pedoman wawancara yang telah terstuktur. Studi dokumentasi adalah salah satu metode pengumpulan data kuallitatif dengan melihat atau menganalisis dokumendokumen yang dibuat oleh subjek sendiri atau oleh orang lain tentang subjek ${ }^{10}$. Penelitian ini juga menggunakan studi kepustakaan yang dilakukakan dengan cara membaca buku, dokumen-dokumen, undang-undang, dan peraturan daerah yang ada hubungannya dengan penelitian yang akan dilaksanakan mengenai implementasi Peraturan Daerah Kota Padang Nomor 3 Tahun 2015 tentang pemenuhan dan perlindungan hak-hak penyandang disabilitas.

Penelitian ini dianalisis dengan menggunakan teknik analisis data dari Miles dan Huberman. Menurut Miles dan Huberman, kegiatan analisis terdiri dari tiga alur kegiatan yang terjadi secara bersamaan, yaitu reduksi data, penyajian data, dan penarikan kesimpulan/verifikasi.

\section{Hasil}

Pemerintah Kota Padang telah menyediakan aksesibilitas fisik untuk penyandang disabilitas. Adapun aksesibilitas tersebut adalah guiding block, Pedestrian Light Controlled Crossing (Pelican Crossing/ Tombol Penyebrangan), ram, Handrail, Braille, Prioritas Tempat Duduk (Priority Seat) angkutan umum Trans Padang serta Pelican Crossing/ Pedestrian Light Controlled (Tombol penyebrangan).

Guiding block adalah Guiding block (jalur pemandu) adalah jalur yang digunakan untuk membantu memberikan informasi perjalanan bagi penyandang disabilitas dengan memanfaatkan tekstur ubin sebagai pengarah dan peringatan. Jalur pemandu inilah yang dimanfaatkan oleh penyandang tunanetra sebagai pedoman dalam berjalan. Jalur pemandu sudah ada dibeberapa pedestrian yang tersebar di jalan-jalan Kota Padang. Dari observasi yang telah dilakukan, jalur pemandu ini terdapat di Jalan Permindo, Jalan Ujung Gurun, Jalan Pattimura, Jalan M. Yamin, Jalan Veteran, Jalan Olo Ladang, Jalan Hang Tuah, Jalan Gereja, Jalan Pasar Baru, dan Jalan Jendral Sudirman.

Ram atau jalan landai merupakan elemen pokok yang sangat penting bagi penyandang disabilitas. Ram adalah salah satu aksesibilitas yang memudahlan pengguan kursi roda dalam memasuki atau menaiki sebuah bangunan. Ram juga bermanfaat bagi lansia, ibu hamil, serta anak-anak. Ram di Kota Padang terdapat di pedestrian yang bersatu dengan guiding block.

Handrail adalah salah satu aksesibilitas fisik yang dapat membantu penyandang tunadaksa dalam melakukan kegiatannya. Handrail merupakan rangkaian peralatan yang berfungsi sebagai alat bantu jalan atau pemegang yang berfungsi untuk membantu penyandang disabilitas dalam berjalan. Pemerintah Kota Padang telah memberikan aksesibilitas ini pada bangunan pemerintahan seperti yang ada di Balai Kota Padang.

Priority Seat (tempat duduk prioritas) adalah aksesibilitas selanjutnya yang diberikan oleh pemerintah Kota Padang untuk penyandang disabilitas. Tempat duduk prioritas ini khusus dibuat untuk orang tua lanjut usia, ibu hamil, penumpang yang membawa anak-anak, dan penyandang disabilitas. Priority Seat ini berada di depan pintu masuk angkutan umum

\footnotetext{
${ }^{8}$ A Muri Yusuf, Metode Penelitian Kuantitaif, Kualitatif \& Penelitian Gabungan, (Jakarta: KENCANA, 2014), hlm. 384

${ }^{9}$ Ibid, hlm. 372

${ }^{10}$ Haris Herdiansyah, Metode Penelitian Kualitatif Untuk Ilmi-ilmu Sosial, (Jakarta: Salemba Humanika, 2014), hlm. 143
} 
Dio Yoan Sabrina, Erianjoni Erianjoni

Implementasi Peraturan Daerah Nomor 3 Tahun 2015

Tentang Pemenuhan dan Pelindungan Hak-hak Penyandang Disabilitas di Kota Padang

Trans Padang yang memudahkan orang tua lanjut usia, ibu hamil, penumpang yang membawa anak-anak, dan penyandang disabilitas agar dapat langsung menduduki tempat duduk tersebut. Pemerintah juga tidak lupa membuat Pelican Crossing/ Pedestrian Light Controlled (Tombol penyebrangan) adalah aksesibilitas yang dibuat oleh pemerintah Kota Padang untuk mempermudah penyandang disabilitas dalam menyebrangi jalan. Pelican crossing ini dibuat bersamaan dengan dibuatnya kawasan ramah disabilitas Kota Padang yaitu Jalan Permindo yang diresmikan pada akhir tahun 2016.

Setelah menyediakan aksesibilitas untuk penyandang disabilitas, pemerintah Kota Padang juga telah mensosialisasikan aksesibilitas tersebut. Sosialisasi tersebut dilakukan pemerintah Kota Padang dengan cara sosialisasi oleh Dinas Sosial Kota Padang pada tingkat Kecamatan dengan mengundang tokoh-tokoh yang ada di Kecamatan serta tingkat Kota yang dilakukan di Aie Pacah, sosialisasi kawasan ramah disabilitas di Jalan Permindo, sosialisasi pada Hari Disabilitas Indonesia yang dilakukan langsung oleh Walikota Padang, sosialisasi oleh Dinas Sosial dan bekerjasama dengan Radio Republik Indonesia (RRI) dengan mengadakan sesi tanya jawab oleh Kepala Dinas Sosial, sosialisasi yang dilakukan Pemerintah Kota Padang dengan mengundang berbagai organisasi Disabilitas di Kota Padang, serta sosialisasi aksesibilitas penyandang disabilitas dengan menggunakan spanduk agar diketahui oleh masyarakat Kota Padang.

\section{Pembahasan}

Peraturan Daerah Nomor 3 Tahun 2015 tentang pemenuhan dan perlindungan hak-hak penyandang disabilitas tentunya merupakan sebuah komitmen dan kesungguhan Pemerintah Daerah Kota Padang dalam memenuhi dan melindungi hak-hak yang seharusnya didapatkan oleh penyandang disabilitas. Peraturan Daerah ini ditetapkan oleh Walikota Padang yaitu Mahyeldi Ansharullah pada tanggal 9 Maret 2015 dan mulai berlaku pada hari itu juga.

Dalam mengimplementasikan Peraturan Dearah Kota Padang Nomor 3 Tahun 2015, pemerintah Kota Padang telah membuat aksesibilitas fisik untuk penyandang disabilitas. Aksesibilitas ini dibuat karena adanya tujuan yang ingin dicapai (Goal Attainment) oleh pemerintah Kota Padang. Adapun tujuan dari pembuatan aksesibilitas untuk penyandang disabilitas yaitu melindungi dan memenuhi hak-hak penyandang disabilitas, menjadikan penyandang disabilitas sebagai individu mandiri yang tidak banyak bergantung pada orang lain, serta memberdayakan penyandang disabilitas.

Aksesibilitas untuk penyandang disabilitas telah dibuat oleh pemerintah Kota Padang satu persatu. Dimulai dari adalah guiding block, Pedestrian Light Controlled Crossing (Pelican Crossing/ Tombol Penyebrangan), ram, Handrail, Braille, Prioritas Tempat Duduk (Priority Seat) angkutan umum Trans Padang serta Pelican Crossing/ Pedestrian Light Controlled (Tombol penyebrangan). Semua aksesibilitas ini sudah mulai menjamur di Kota Padang.

Namun pada kenyataannya, masih banyak masyarakat Kota Padang yang tidak mengetahui keberadaan aksesibilitas tersebut. Padahal, aksesibilitas yang telah dibuat digunakan dan dimanfaatkan oleh masyarakat Kota Padang untuk melakukan aktivitasnya sehari-hari. Beberapa pedagang bahkan menjajahkan dagangannya tepat di atas guiding block pada pedestrian yang ada di Tapi Lauik (Taplau) Pantai Purus Padang. Mereka berjualan kerupuk kuah, air mineral, langkitang cucuik, pensi, serta menyewakan mobil-mobilan dan skuter tepat di atas jalur pemandu yang seharusnya digunakan oleh penyandang tunanetra sebagai pedomannya dalam berjalan. 
Dio Yoan Sabrina, Erianjoni Erianjoni

Selain itu, ram yang telah dibuat khusus sebagai jalur pengguna kursi roda untuk memasuki sebuah bangunan juga masih disia-siakan keberadaannya. Dari hasil observasi yang telah dilakukan, masih ada masyarakat Kota Padang yang memarkirkan kendaraannya tepat di depan ram sehingga menutup akses penyandang disabilitas untuk menaiki sebuah pedestrian di Jalan Permindo.

Pada akhir tahun 2016, pemerintah Kota Padang telah meresmikan kawasan ramah disabilitas Kota Padang yaitu pada Jalan Permindo. Kawasan ini banyak diketahui oleh masyarakat Kota Padang khususnya penyandang disabilitas. Dalam kawasan ramah disabilitas ini terdapat 3 aksesibilitas di dalamnya, yaitu guiding block, ram, dan pelican crossing. Kawasan ramah disabilitas ini tertata rapi, tidak ada pedagang nakal yang berjualan dan menganggu kenyamanan pengguna aksesibilitas tersebut. Pada kawasan ramah disabilitas, terdapat tiga aksesibilitas di dalamnya yaitu guiding blokc, ram, dan pelican crossing. Namun setelah melakukan observasi, pelican crossing yang ada di kawasan ramah disabilitas ini sudah dalam keadaan mati dan tidak dapat digunakan lagi.

Upaya pemerintah Kota Padang dalam mewujudkan pemenuhan dan perlindungan hakhak penyandang disabilitas melalui aksesibilitas harus diapresiasi. Aksesibilitas-aksesibilitas yang telah dibuat sedikit banyak telah membantu mewaujudkan pemenuhan dan perlindungan hak-hak disabilitas. Namun kesadaran dan pengetahuan masyarakat akan aksesibilitas ini masih kurang. Hal ini berkaitan dengan sosialisasi yang dilakukan oleh pemerintah Kota Padang. Aksesibilitas yang dibuat oleh Pemerintah Kota Padang harus disosialisasikan kepada seluruh masyarakat. Ketika aksesibilitas tersebut telah disosialisasikan oleh Pemerintah Kota Padang, maka pengetahuan masyarakat terhadap aksesibilitas untuk penyandang disabilitas pun akan bertambah. Dengan bertambahnya pengetahuan masyarakat tersebut, diharapkan baik pemerintah maupun masyarakat akan menyesuaikan diri dengan aksesibilitas yang ada, agar aksesibilitas yang dibuat dapat digunakan sesuai dengan fungsi dan tujuannya. Hal ini sesuai dengan pernyataan Parsons mengenai fungsi adaptation (adaptasi), di mana masyarakat beradaptasi dengan sistem yang ada agar goal dapat tercapai.

Melalui Dinas Sosial Kota Padang, pemerintah mulai mensosialisasikan Peraturan daerah Kota Padang Nomor 3 Tahun Tahun 2015 yang dimulai dari tingkat Kecamatan sampai ke tingkat Kota. Dalam sosialisasi ini turut mengundang perangkat-perangkat penting ditingkat Kecamatan dan perangkat-perangkat penting di Tingkat Kota. Diharapkan dengan menghadirkan perangkat penting ditingkat Kecamatan maupun Kota, nantinya ilmu yang didapatkan dari sosialisasi tersebut dapat dibagi keseluruh lapisan anggota masyarakat.

Pada saat peresmian kawasan ramah disabilitas Kota Padang di Jalan Permindo, pemerintah juga memberikan sosialisasi mengenai aksesibilitas untuk penyandang disabilitas. Hal ini dilakukan agar masyarakat Kota Padang mengetahui tujuan dari dibuatnya kawasan ramah disabilitas. Dalam sosialisasi ini, pemerintah juga mengundang penyandang disabilitas dan mempersilahkan penyadang disabilitas untuk menggunakan aksesibilitas yang ada.

Setiap tanggal 3 Desember diperingati sebagai Hari Disabilitas Indonesia (HDI). Setiap tanggal itu, Dinas Sosial Kota Padang bekerjasama dengan RRI (Radio Republik Indonesia) membuat sebuah forum untuk melakukan sesi tanya jawab mengenai disabilitas langsung oleh Kepala Dinas Sosial Kota Padang. Dalam memperingati Hari Disabilitas Indonesia, pemerintah juga selalu melakukan acara-acara di mana nantinya selalu ada sosialisasi dari Walikota Padang mengenai aksesibilitas untuk penyandang disabilitas.

Pemerintah Kota Padang telah membuat dan menjalankan komitmennya untuk memenuhi dan melindungi hak-hak penyandang disabilitas. Hal ini dapat dilihat dari usaha pemerintah Kota Padang dalam menyediakan dan mensosialisasikan aksesibilitas untuk penyandang disabilitas. Namun, dalam implementasinya masih belum sesuai dengan tujuan. 
Dio Yoan Sabrina, Erianjoni Erianjoni

Implementasi Peraturan Daerah Nomor 3 Tahun 2015

Tentang Pemenuhan dan Pelindungan Hak-hak Penyandang Disabilitas di Kota Padang

Dari wawancara yang telah dilakukan, pemerintah Kota Padang belum membuat TP2HD (Tim Pemenuhan dan Perlindungan Hak-hak Penyandang Disabilitas). Ada pun tugas dari TP2HD adalah sebagai berikut ${ }^{11}$.

1) Memberikan pertimbangan, saran, dan usul kepada pemerintah daerah dalam pemenuhan dan perlindungan hak-hak penyandang disabilitas;

2) Melaksanakan penelitian, pengkajian, pemantauan, evaluasi, dan pengendalian umum kebijakan dan program upaya pemenuhan dan perlindungan hak-hak penyandang disabilitas;

3) Menerima, meneliti serta mengkaji saran dan pertimbangan dari masyarakat.

Dari penjelasan di atas, dapat dilihat bahwa tugas TP2HD sangat berpengaruh dalam mengimplementasikan Peraturan Daerah Kota Padang Nomor 3 Tahun 2015. Padahal tugas dari TP2HD ini sangat penting dan sangat berpengaruh terhadap implementasi peraturan tersebut.

Namun kekurangan-kekurangan serta kendala-kendala yang dihadapi pemerintah Kota Padang tidak membuat komitmen pemerintah untuk mewujudkan pemenuhan dan perlindungan hak-hak penyandang disabilitas menjadi pudar. Dari sini pemerintah Kota Padang belajar dan mencari berbagai strategi agar Peraturan Daerah Kota Padang terimplementasi dengan baik dan sesuain dengan tujuan.

\section{Kesimpulan} berikut.

Berdasarkan hasil penelitian yang peneliti lakukan di Kota Padang adalah sebagai

1. Ada pun aksesibilitas untuk penyandang disabilitas di Kota Padang sudah ada dan mulai tersebar di beberapa titik, yaitu: a).Guiding block di pedestrian pada jalan Permindo, Jalan Ujung Gurun, Jalan Pattimura, Jalan M. Yamin, Jalan Veteran, Jalan Olo Ladang, Jalan Hang Tuah, Jalan Gereja, Jalan Pasar Baru, dan Jalan Jendral Sudirman; b). Ram sebagai akses untuk memasuki sebuah bangunan atau trotoar di beberapa pedestrian dan bangunan pemerintahan; c). Handrail di kantor pemerintah Balai Kota Padang dan Kantor Dinas Sosial Provinsi Sumatera Barat; d). Braille untuk memudahkan penyandang tuna netra dalam mengurus administrasi; e). Prioritas tempat duduk (Priority Seat) untuk penyandang disabilitas pada angkutan umum yaitu bus Trans Padang; f). Pedestrian Light Controlled Crossing (Pelican Crossing) yang ada di Jalan Permindo.

2. Sosialisasi yang diberikan pemerintah mengenai aksesibilitas untuk penyandang disabilitas sudah dilakukan. Adapun sosialisasinya yaitu: a). Sosialisasi aksesibilitas penyandang disabilitas yang dilakukan oleh Dinas Sosial Kota Padang pada tingkat Kecamatan dengan mengundang tokoh-tokoh yang ada di Kecamatan; b). Sosialisasi aksesibilitas penyandang disabilitas yang dilakukan oleh Dinas Sosial Kota Padang pada tingkat Kota yang dilakukan di Aie Pacah; c). Sosialisasi kawasan ramah disabilitas di Jalan Permindo; d). Sosialisasi aksesibilitas penyandang disabilitas pada Hari Disabilitas Indonesia yang dilakukan langsung oleh Walikota Padang; e). Sosialisasi aksesibilitas penyandang disabilitas oleh Dinas Sosial dan bekerjasama dengan Radio Republik Indonesia (RRI) dengan mengadakan sesi tanya jawab oleh Kepala Dinas Sosial; f). Sosialisasi aksesibilitas penyandang disabilitas yang dilakukan Pemerintah Kota Padang

11 Peraturan Daerah Kota Padang, Peraturan Daerah Kota Padang Nomor 3 Tahun 2015 tentang Pemenuhan dan Perlindungan Hak-hak Penyandang Disabilitas, BAB VII, Pasal 140, Ayat 1-2, Hlm. 37 
Dio Yoan Sabrina, Erianjoni Erianjoni Implementasi Peraturan Daerah Nomor 3 Tahun 2015 Tentang Pemenuhan dan Pelindungan Hak-hak Penyandang Disabilitas di Kota Padang

dengan mengundang berbagai organisasi Disabilitas di Kota Padang; g). Sosialisasi aksesibilitas penyandang disabilitas dengan menggunakan spanduk agar diketahui oleh masyarakat Kota Padang. Sosialisasi ini dilakukan dengan tujuan memperkenalkan dan memberitahu bahwasanya Pemerintah Kota Padang memiliki aksesibilitas untuk penyandang disabilitas. Hal ini sangat berguna dalam keberhasilan pemerintah memenuhi dan melindungi hak-hak penyandang disabilitas di Kota Padang.

3. Peraturan Daerah Kota Padang Nomor 3 Tahun 2015 belum terimplementasi dengan baik. Hal ini terjadi karena informasi dari sosialisasi yang dilakukan belum tersebar hingga keseluruh lapisan masyarakat. Hanya sebagian masyarakat yang mengatahui aksesibilitas untuk penyandang disabilitas yang dibuat oleh Pemerintah Kota Padang. Hubungan internal pemerintah Kota Padang juga belum terbina dengan baik. Ini tampak dari belum terbentuknya Tim Pemenuhan dan Perlindungan Hak-hak Penyandang Disabilitas (TP2HD).

\section{Daftar Pustaka}

Fernandes, R. (2018). Adaptasi Sekolah Terhadap Kebijakan Pendidikan Inklusif. SOCIUS, 4(2 December), 119-125.

Herdiansyah, Haris. (2014). Metode Penelitian Kualitatif untuk Ilmu-ilmu Sosial, Jakarta: Salemba Humanika.

Peraturan Daerah Kota Padang. No 3 tahun 2015 tentang Pemenuhan dan Perlindungan HakHak Penyandang Disabilitas

Sugiyono. (2017). Metode Penelitian Kuantitatif Kualitatif dan R\&D. Bandung: Alfabeta.

Undang-Undang Republik Indonesia, Undang-undang RI Nomor 8 Tahun 2016 tentang Penyandang Disabilitas

Sukmadinata, Nana Syaodih. (2007). Metode Penelitian Pendidikan. Bandung: PT. Remaja Rosdakarya.

Yusuf, A Muri. (2014). Metode Penelitian Kuantitaif, Kualitatif \& Penelitian Gabungan. Jakarta: Kencana.

Herdiansyah, Haris. (2014). Metode Penelitian Kualitatif untuk Ilmu-ilmu Sosial, Jakarta: Salemba Humanika. 